\title{
WORKFORCE LOCALIZATION IN THE KINGDOM OF SAUDI ARABIA: AN ONTOLOGICAL PERSPECTIVE
}

\author{
Mohamed Elgeddawy \\ Prince Mohammad Bin Fahd University \\ melgeddawy@pmu.edu.sa
}

\begin{abstract}
Nowadays there is an increasing interest in the localization of manpower in the countries of the Gulf Cooperation Council in general and in the Kingdom of Saudi Arabia (KSA) in particular to combat the unemployment rates that have been on the rise over the last ten years according to government reports. This study focuses on workforce localization in the context of Saudi Arabia. In this regard, it is noticeable that the progress towards the implementation of the localization policies in the KSA oftentimes faces challenges and obstacles. This article presents solutions that stimulate stakeholders (such as academicians, policy makers, employers and university students) to be engaged dialogically in promoting a new conceptual perception of what it means to localize manpower. The purpose of the article is twofold: First, it critically reviews progress Saudi Arabia has made towards workforce localization as presented in the literature by both policy reports and academic experiential research. Second, it presents a new ontologically-oriented hermeneutic reading of workforce localization in the KSA. The overall goal is to advance a hermeneutic dialogue among key stakeholders on what it means to localize Saudi workforce. The article brings about a new ontological insight of manpower localization that assists in developing employable national human resources.
\end{abstract}

Keywords: Localization, Foreign Workforce, Ontology, Hermeneutics

\section{Introduction}

Over the last 25 years or so, there has been a significant amount of research on the localization of human resources in the Kingdom of Saudi Arabia (KSA) as well as in many other developing countries of the Gulf Cooperation Council (GCC). In this domain, research across the GCC countries relates the emergence of manpower localization as a concept and practice to an increase in the unemployment rates which these countries experience (Swailes, et al., 2012). The concept of manpower localization is referred to in the context the KSA as Saudization and it reflects various perspectives and a considerable debate about its definitional issues, success factors, and scope which remain controversial. As a public policy, Saudization has been the focus of research of many national academic studies addressed by a broad range of literatures: Human resource development (Achoui, 2009; Aldossary and Rahman, 2005), talent management (Sadi, 2013), knowledge transfer (Madhi and Barrientos, 2003), and knowledge sharing and skill development (Fakeeh, 2009; and Forstenlechner, 2009). As a national policy for workforce, it goes as far back as the Saudi labor decree of the 1969 which necessitated that $75 \%$ of the workers of any private sector must be Saudis; yet, "the 1969 royal decree has never been implemented or enforced during the oil boom era of the KSA" (Al Sheikh, 2015, p.4).

The following review of academic and policy literatures on localization of human resources in the KSA is limited to the span from 1991 to 2016. It is limited to policy reports, theories, and empirical research that inform the construction of Saudization as a concept and a set of practices. For reliability purposes, only policy reports issued by governmental sectors or prominent national and international organizations are included. Policy reports, conceptual and empirical studies that are not directly related to localization of human resources in the Kingdom of Saudi Arabia are excluded. The inclusion or exclusion of independent reports is based on the grounds of who said what, why, when, and in what context and capacity. That is, who is the author, what is his / her position and whether her / his background is relevant to the main themes of the report; when, where, why, and how the report is generated and whether the report represents a personal view that is not grounded on observation, experience or actual research; to whom the report is directed and where it is published, is it published 
on a government website or on website of a prominent, reliable, and reputable author or business leader? What is the unsaid messages that stand behind the argument of the reports, their political implications, and whose interests do these messages serve?

\section{Progress towards localization policy in Saudi Arabia}

The Progress towards localization of human resources in the Kingdom of Saudi Arabia (KSA) is discussed in relation to a number of themes that emerged from a critical analysis of policy and academic literatures, specifically:

- Saudization is predominantly perceived as a replacement of foreign labor force with Saudi nationals.

- Saudization is related to a rise in the unemployment rate and dependence of private sector on foreign labor.

- Saudization is positively perceived by college graduates and the government sector.

- Saudization is perceived negatively by private sectors' employers.

- Saudization is related to the inability of the Saudi educational system to generate skilled workforces needed by the labor market.

- Saudization literature spotlights a lack of coordination between policy makers and private sectors' employers.

- Saudization focuses on enforcing a quota system in achieving its far-fetched goal for replacing foreign labors with Saudi nationals.

- Saudization literature is diverse, heterogeneous, and lacks a shared meaning with two main strands: Public policy literature and another empirical academic strand that is perspective oriented.

- Saudization is conceptualized in the literature epistemologically rather than ontologically.

\section{Definitional concepts}

The concept of Saudization or nationalizing the human resources in Saudi Arabia is not new. Al Sheikh (2015) historicized the concept and traced its origin to as far back as to the labor law of the 1969 which decreed that $75 \%$ of private sector workforce must be Saudis. Generally, the time-honored definition of Saudization is related to the replacement of expatriates with nationals in both public and private sectors. It also implies giving priority to Saudi contractors. Another definition considers Saudization in terms of offering education and training to enable national workforce to replace expatriates (Al Dossary and Rahman, 2005; Al Humiad, 2005; Al Shanbrie et al., 2014).

Important to note, Saudization as a replacement of foreign workforces with national Saudis was never implemented or enforced on the private sector in the 1960s and 1970s. This is as it is because the 1960s experienced growth of national workforces especially in the private sector of the oil industry as shown in figure one.

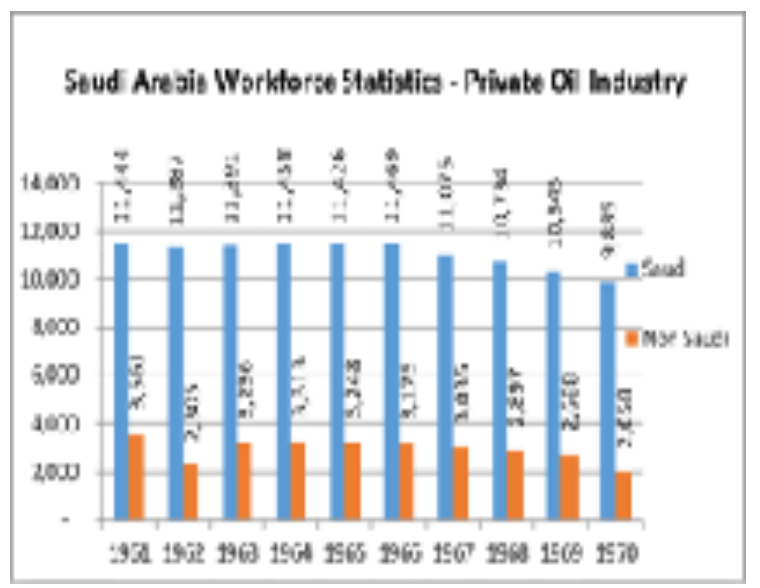

Figure 1; Source: Central Department of Statistics and Information, KSA, 2016.

Significantly, over a very short time, the oil revenue had its positive impact not only on the Saudi labor market where new jobs were created but also on higher education enrollment and graduation rates. Figure two and three illustrate this point.

Enrollment of Post-Secondary 


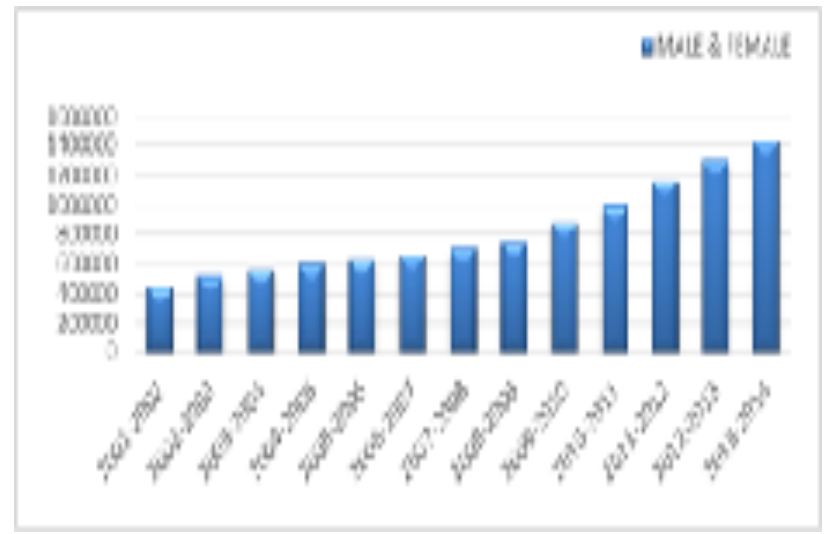

Figure 2; Source: Central Department of Statistics and Information, KSA, 2014

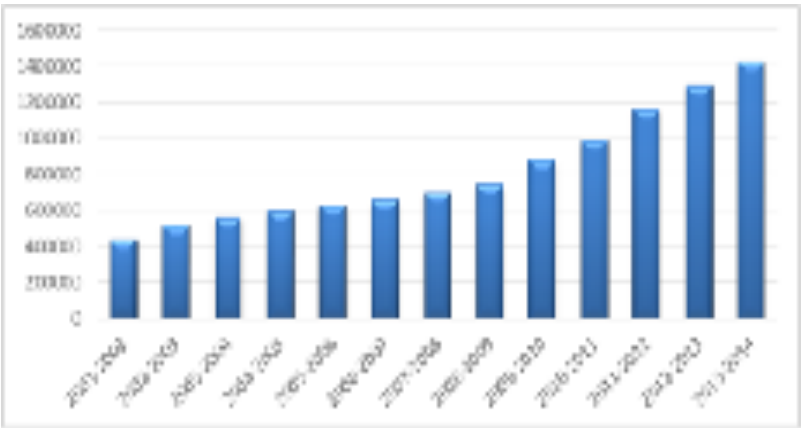

Figure 3 : Central Department of Statistics and Information, KSA, 2014

The increase in graduation rates raised the ratio of the Saudi national workforce. In addition, the creation of new jobs also raised the ration of expatriates' workforce. Worth mentioning is that the current total workforce of the Kingdom is $11,686,115$ million, 5,003,618 of whom are nationals and $6,682,497$ are expatriates. Although the workforce ratio of both non-Saudis and Saudi nationals has been on the rise due to economic growth, the time series data in figure four shows that foreign labor force ratio exceeds that of the nationals from the 1980 to 2016.

\section{Enforcement of Saudization on private sector}

According to the above mentioned figure, although the economic growth of Saudi Arabia has its positive impact on higher education's enrollment and graduation rates and new jobs were created, not all these jobs were for Saudi nationals. Recent statistics show that the unemployment rate is estimated to be at 11.6\% (Central Department of Statistics, KSA, 2016). That said, the increase in the number of university graduates and the inability of the government to provide them with jobs made it compelling to enforce the localization of the human resources in the private sector. Towards the goal of enforcing Saudization, the government initiated a quota system which forces private companies to have a percentage of their manpower from national workforces.

\section{Saudization and the quota system}

To ensure that the quota policy is being strictly implemented, the Saudi Ministry of Labor periodically inspect, through a team of inspectors, private sector companies to check whether they comply with the quota policy. Private companies that prove non-compliance are subjected to a fine (Al Shanbri et al., 2015). As a result, the quota system has led many businesses to close. Despite these strict regulations, the Saudi government could not achieve its targeted goal of localizing Saudi human resources.

However, not only do government organizations and offices support and endorse the quota system and Saudization, but other stakeholders as well. A great number of academic research studies provide detailed analysis of college students' positive perspectives toward Saudization and the quota system. 


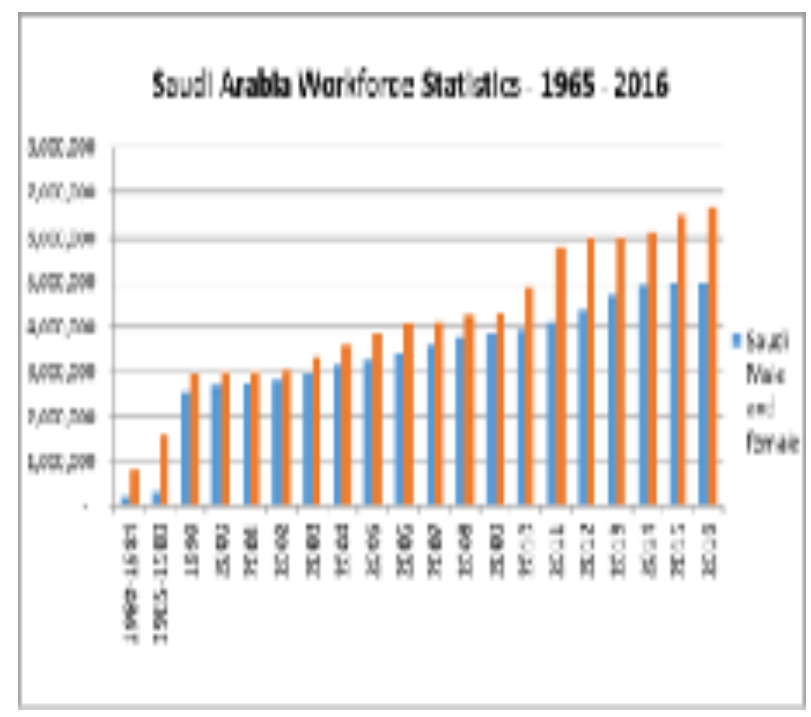

Figure 4; Source: Central Department of Statistics and Information, KSA, 2016.

\section{Research on Saudization: Student perspective}

As early as the 1990, Alogla (1990) investigated the perception of 1032 Saudi college students from 9 universities across the Kingdom on the factors that facilitate or impact the implementations of localizing the workforce in the private sector. The study reported that students of the 1990s highly valued the substitute of foreign labor by Saudi nationals; the majority of the participants of the study favored the issuance of laws and regulations to facilitate rules of law regarding the strict implementation of Saudization. Remarkably, the study reported that Saudi students of 1990s expressed their willingness to accept jobs that would have been rejected by older generations. This is as it is due to rapid change that the Saudi society has been witnessing including increase in the enrollment and graduation rates of university students.

In addition, Alogla's (1990) study indicated that the majority of the surveyed students also stated that they are willing to work for the private sector as long as it satisfies their potential financial needs and sense of job security. These findings challenge the time-honored Saudi mindset of preferring to work in public sector. The findings of Alogla's study show that the majority of Saudi students of the 1990 are for Saudization and they don't consider themselves to be lacking the skills that the private sector needs. Significantly, recent studies support Alogla's past findings and indicate that Saudi university students and graduates are in favor of the immediate replacement of expatriates with Saudi nationals. Yet, contrary to college students' positive attitude towards Saudization is that of private sectors' employers who identify challenges and obstacles towards the progress to Saudization.

\section{Research on Saudization: Employer perceptive}

A number of studies (Alogla, 1990; Al Humaid, 2003; Alotaibi, 2014) listed various obstacles to the localization of manpower in the private sector, indicating that both employers and job seekers perceived hindrances related to:

- Lack of required job market skills.

- A mismatch between the competencies and qualifications that the private sector requires and the earned degrees of the job seekers which predominately are based on background in Islamic studies and social sciences whereas the job market needs skilled engineers and technicallyoriented graduates .

- Lack of training centers.

- Deficiency in the public education role in preparing qualified and skilled graduates.

- No participation of private sector in training graduates.

- No collaboration among private sector, educational institutions, and government organizations regarding the practical implications of enforcing Saudization.

- Refusal of Saudis to hold manual work.

- Existing social constraints and social image that prevent Saudis from accepting manual work. 
- Lack of community and media support of the Saudization concept and its practical implementation.

Noticeably, a growing body of national literature identified the mismatch that exists between the supply of higher education institutions and the Saudi labor market skill demands to stand as the main obstacle to the implementation of Saudization. Other obstacles are related to compensation where employers consider hiring expatriates as more beneficial and economical than hiring Saudis. Another obstacle relates to private sector requirement of English language which the majority of graduates lack. Also, Saudis expect managerial positions while lacking the skills that qualify them for this purpose. For example, Madhi and Barrientos (2003) examined the impact of nationalizing the workforce in Saudi Arabia on the reduction of foreign labor force especially during the 1995 which witnessed reduction in the oil prices, the outcome of which was the reinforcement of Saudization policies to reduce unemployment rates among Saudi youth. The study indicates that employers emphasize that before imposing the implementation of Saudization, graduates must be trained and empowered with the skills and competences that today's labor market requires.

\section{Saudization: Lack of a shared meaning}

Various other studies consider the Saudization phenomenon from different perspectives. Al Dossary (2004) considers skill development as a strategic inevitable initiative for nationalizing workforce in the KSA to close the perceived gap that exists between labor skill profiles and graduates' profiles. Al Jarallah (2004), in much the same way of Al Dossary (2004), relates existing challenges of Saudization to the inability of the educational system to prepare its graduates with the skills that the market needs. So, reforming school and higher education curriculum become an unavoidable necessity to generate skilled and qualified graduates who can compete in a globally skill-oriented economy and society such as that of the KSA. Aldossary's (2004) report calls for a paradigm shift in the Saudi educational system; a shift of focus from memorization to a focus on critical thinking, problem solving, and conflict management, and other lifelong learning skills.

In contrast, Al Shammari (2009) considers the national workforce as unsuccessful due to the bureaucratic involvement of the government which control skill formation institutions known as "Organization for Technical Education and Vocational Training (GOVTEVT)" (p. 4), the function of which is to provide private sector with skilled and qualified Saudi workforce. Al Shammari returns the failure of Saudization strategy in the private sector to the inability of GOTEVT in providing skilled labors who can meet the demands of the Saudi business market. The study indicates that the vocational and skill formation of government organizations focus on quantity rather than quality of graduates and their curriculum stresses memorization of knowledge rather than its practical application. Learning by doing, experimental learning, and inquiry-based learning are absent from the educational systems that are supposedly concerned with skill formation.

Unfortunately, the GOTEVT reports, according to Al Shammari, perceive the performance of these government skill-formation organizations as great and their graduates as employable, whereas the analysis of interviews of employers of these graduates indicate that they lack the required skills needed for employment and that companies such as ARAMCO and SABIC employ them just to satisfy the percentage of Saudization. Al Shammari's study indicates that these graduates have to be trained again in their company training centers to uplift their employability skills. The conclusion of Al Shammari's (2009) study substantiates that the quota system is not yet supporting the country's long term planning and vision.... [and] that "Saudization is hindered by a lack of skills, knowledge, and attitude provided by GOTEVT and other government skill formation bodies" (p.280).

\section{Saudization: Lack of coordination}

Lack of coordination and understanding between government agencies and private sector regarding the implementation of Saudization and the causes that stand behind it always exists. "The ministry is not listening to private sector's Saudization side of the story.... These quotas are disrupting organizations' performance" (Al Shammari, 2009, p. 286). Likewise, Al Dossary and Rahman (2005) calls for a coordination that needs to be initiated among all stakeholders such as government agencies, private sector companies, and the public on what Saudization is, what type of nationalization is needed, why and how to implement it. That is, the time-honored quota system did not and will not sustain a national strategy such as that of Saudization which requires strong vocation and high education system that should ensure generating skilled and qualified competitive workforces. 


\section{Quota policy: A failure in the private sector}

Many other studies return failure of the quota system to the inability of the Saudi system to generate skilled work force needed by the labor market. Harry (2007) states that the private sector will continue to resist the quota policy until the reform of the educational system takes place and generate productive and competent workforce. He calls for a collaborative endeavor among the government agencies, employers, and citizens of all the GCC countries to build a productive and highly educated workforces that can take on the responsibility of developing their countries rather than depending on expatriates. According to Maghrabi (2007), the Saudi banks can't adhere totally to the implementation of Saudizing the banking system due to lack of required qualifications, experience, and skills, especially at managerial banking position levels. The results of the study indicate that the key to solving the increase in unemployed rates is to create meaningful jobs that suit the qualifications and skills of higher education graduates.

In much the same way, Sadi and Al Buraey (2009) qualitatively examined the extent to which Saudization policy has been successful so far. The study came to the conclusion that Saudization is implemented by force and not through "reasoning and persuasion" and that it is successful in the government sector and failed in the private sector. The study advances a shift from the enforcement of Saudization through quota's rules and policies to another focus on building skilled labor forces that can compete in a competitive labor market. Noticeably, Saudization literature is diverse, heterogeneous and lacks a shared meaning with two main strands: policy literature and another strand that focuses on experimental academic literature.

\section{Saudization: Otherizing the Other}

Official government reports (Al-Kibsi et al., 2015; SAGIT, 2016) indicate that localization policies had been implemented successfully across private sectors organizations whereas education researchers indicate the existence of challenges, obstacles, and limitations of superficial implementation of Saudization policies. Educational research indicates that the private sector stakeholders implemented the Saudization policies just to superficially show compliance with the new mandated regulations without making instrumental changes in the makeup of their workforces.

On the other side of the continuum, Al Dossary (2004) called for a reduction of the foreigners in the labor force due to what he calls 'economic drawbacks' represented by creating a competitive labor market which leads Saudis to be unemployed. Another factor of the economic drawbacks is considered in relation to the amount of money that expatriates have to transfer. A third reason for the reduction of the foreign labor forces relates to what Al Dossary considers a 'threat' to the socio-cultural norms and values of Saudi Arabia due to the existence of various cultures. He believes that the foreign labor forces "undermine" Saudis' ability to perform. He goes farther to claim that there is no need to invest in developing human resources development programs unless getting rid of foreign workers who represent "a threat to national human resource programs". Also, he calls for the Saudization of all administrative positions in the private sector to provide Saudis with ample opportunities to "control" important and key positions in all administrative sectors.

Unfortunately, Al Dossary's plan for substituting foreigners with national workforce did not take into consideration the expertise, talent, and situated knowledge of the foreign manpower that he wants to release and substitute. No plan for knowledge sharing has been suggested. In this context, the epistemological focus is on what should be done to expedite the process of manpower localization; that is, first, let's define the process of Saudization to achieve one definite goal of substituting foreign labors with Saudi Nationals. He does not see a value in the existing professional skilled Other. The professional Other is perceived not as an asset but as a burden that needs to be released. Though, he calls for addressing the gap between education and training systems output and labor market skill demands, his epistemologically-oriented solutions for localizing Saudi manpower did not allow him to view the Self (national workforce) in relation to another professional different Other (foreign labors). The epistemological mindset, according to Rescher's ( 2003) notion of espistemology, that dominated the Al-Dossary's perception did not allow him to see an inevitable desired value in connecting the Self to the different professional Other. Focusing on defining existing concepts and finding practical applications for fulfilling the requirements of localizing human resources has deprived the researcher from developing a hermeneutic, ontological understanding of the factors that negatively impact the practical application of Saudization in the private sector.

\section{Predominance of epistemological perspectives}


It is noticeable that a significant amount of research published on Saudization is epistemologicallyoriented. As a concept, epistemology focuses on explaining concepts and defining them ( Rescher, 2003); it also focuses on what stands behind the implementation of the concept. It is a philosophical trend that concerns itself with what is knowledge and what is not knowledge. Epistemologists also focus on the cognitive process that we go through while learning or applying a concept. They focus more on the process, it is a process-oriented approach; epistemologists' main concern is on how Saudization is being implemented, what factors hinder or facilitate nationalizing the workforce in the KSA and how the policy should be enforced and implemented.

Epistemologists marginalize the ontological understanding of the concept which focuses more on analyzing stakeholders' perspectives towards the goal of establishing a desired hermeneuticallyoriented dialogue among them. Almost all of the available research on manpower localization in the KSA from 1990 to present focuses on stating definitions, perceptions, challenges, hindrances, developing and enforcing strategies related to Saudization. Important to note, an epistemological mindset will never facilitate an insightful dialogue among various stakeholders. It will never lead to the development of a shared meaning of what should be done to address and assess the demands of the labor market as well as the expectations of university graduates. As such, a shift of focus is needed from epistemology to another ontologically-oriented understanding of what it means to nationalize the Saudi workforces. The following section addresses this desired shift of focus that allows the Self (national workfoce) to see itself in relation to the different inevitable Other (foreign manpower).

\section{Towards a paradigm shift from epistemology to ontology}

Given the impact of globalization on the dynamic of the Saudi labor market and the Kingdom's 2030 vision with its focus on preparing qualified and skilled graduates for a knowledge and technologybased economy and society, it is necessary to consider a shift of focus from an epistemological mindset to another ontologically oriented view towards nationalizing labor forces in the Kingdom. The focus of the following discussion is to advance an understanding of the ontology underlying the concept of nationalizing manpower in the KSA, while considering the implications this understanding may have on the role stakeholders (private sector employers, government organizations, academicians, college students, and the public) can / should play in this regard.

The aim of the discussion is to problematize the epistemology underlying the concept of nationalizing the workforce by introducing Heidegger's (1995) and Gadamer's (1977) concepts of 'hermeneutic dialogue' and 'horizon of understanding'; this is a new perspective that advances a different worldview of what it means to nationalize the workforce. Theoretically, ontology is an understanding, interpretation and description of concepts, words and the world within a contextualized certain domain of discourse. That is, it deals with an understanding of the concept within its specific context. The following section presents an ontologically-oriented hermeneutic reading of manpower localization in the KSA.

\section{Ontologically-oriented reading of Saudization}

Ontology is a science of providing an in-depth explanation of all the entities that constitute an understanding of the concept within its situated historical, socio cultural, and political context (Bruce, 1995; Heidegger, 1995; Gadamer, 1977). It is the study of the principles and factors that constitute the meaning of a concept; that is, ontology focuses on meaning making which takes place in accordance with a situated set of constructed beliefs and conventions within a specific time and place. That said, the ontology of nationalizing the workforce in the KSA implies an in-depth understanding of the network of assumptions, belief systems, and relationships related to the concept and its contextualized practical applications.

Given the Saudi National Transformation Program of 2020 with its focus on developing the skills of human resources (KSA 2030 Vision, 2017), it is more important than before to go beyond the epistemological understanding and implementation of Saudization and focus more on the ontology that stands behind it. Focusing on the ontological connotation of the concept involves an understanding of what it means to nationalize the workforce; an understanding that goes beyond the replacement of expatriates with Saudi nationals.

An ontological understanding of Saudization does not promote the replacement of expatriates with Saudi nationals but advances engaging professional experiences and opportunities for both the national and international workforces to be an integral unified part of building the country's economy. In line with the KSA's 2030 vision, ontology expands the concept of Saudization to endorse a sense of national belonging within a specific socio-cultural, economical, historical, and political context. That 
is, an ontological understanding of what it means to nationalize the workforce is strategically related to what it means to be employable in a competitive, developing country that is witnessing a transition from oil-based to knowledge and technology-driven economy and society. An ontologically-oriented hermeneutic reading of Saudization is illuminating in this context.

\section{An ontologically-oriented hermeneutic reading of Saudization}

Hermeneutics is a philosophical view of reading the word and the world and a form of an ontological understanding; it is a way of interpreting concepts within their historical, socio cultural and political contexts (Heidegger, 1995). Hermeneutics, as a philosophical research method, situates the constructed meaning of workforce nationalization within its socio-cultural and political context where what is inhere (concepts related to Saudization policy) is related to what is out-there (the practical applications of the concept). This hermeneutic reading of the nationalization policy in the KSA makes it important to understand what is said and what is unsaid. To explain and understand the concept of work force localization in this domain is to have conscious awareness of the Saudi national identity within its socio-cultural and political constraints and norms of values which resists a dogmatic enforcement of policies and procedures unless individuals get to know what is in these policies for them.

\section{The Self and the Other; An inevitable relationship}

Enlightening the Saudi society of the ontological connotation that stands behind nationalizing the workforce facilitates its implementation. This meaning is absent from the literature, media, and is not part of policy and decision making discourse. Put another way, the ontological discourse of localizing the Saudi workforce needs to go beyond the how and whether it is being implemented. Rather, the center of attention should be on what is in it for each stakeholder and the country? In this context and ontologically speaking, workforce localization implies what it means to be employable nationally and internationally; hence ontological hermeneutics adds a value to our understanding of work force nationalization; it views it as being able to professionally function in the world in relation to the different Other, rather than replacing her/him. Significantly and hermeneutically speaking, we are always already beings in the world with others. That said, rather than codifying the concept in terms of replacement of foreigners with Saudi nationals, localization, from a hermeneutic ontological stance, is to perceive the Self and the Other referentially and differentially. Promoting this ontological understanding necessitates qualifying and preparing skilled nationals who can compete with the different-professional and skilled Other. What follows further explains this concept in relation to Sartre's (1956) notion of "being-for-itself".

\section{Saudization and Sartre's notion of 'being-for-itself'}

Significantly, Saudization from an epistemological perspective perceives its stakeholders ( such as job seekers, employers, and policy makers) in Satre's (1956) notion as "being-in-themselves" who have no free will and beings who have to follow rules and regulations. Hermeneutically, the being-in-itself is not a productive desired mode of existence. Considering an ontological concept of Saudization would allow such stakeholders to have a desired mode of existence, which is according to Sartre's (1956) notion "a being-for-itself"; the world view of "a being-for-itself" gives stakeholders of manpower localization in the KSA a professional mode of making meaning of the process. According to this hermeneutic insight, "a being-for-itself" is someone who brings meaning to the concept and its practical application. When stakeholders of Saudization view themselves as being-for-themselves, they would have free will to choose and bring meaning to their professional and social life and make meaning out of this choice. As "being-for- themselves", stakeholders of workforce localization will diligently work to develop professional employable beings who bring meaning not only to their present but future as well. Considering Saudization's stakeholders as "being-for-themselves" gives them the opportunity to construct and reconstruct their potentialities.

This hermeneutic and ontologically-oriented vision gives stakeholders of Saudization a voice to be honored and life experiences to be validated. It also provides practitioners and policy makers with an understanding that Saudization in itself is an act of being in-the-world with Others. 'A being for itself' is a being who is always already in the world with Others. That is, the Self (the national workforce) and the Other (the expatriates) are interrelated, intertwined, and interdepended. They inevitably exist in the world together and it is inevitably desired to understand each other's referentially and differentially. Since the Self and the Other unavoidably exist in relation to one another, our understanding and application of workforce localization must consider raising the competences and skills of Saudi nationals to compete with the Other (foreign labor force) rather than replacing her/him. 
In this regard, hermeneutics, as an ontological method of inquiry, provides an insight of work force localization as a mode of existence with the Other rather than a codified concept of replacing expatriates with local workforces. That is, there is no codification or big theory or best practices for the application of Saudization that needs to be followed and honored.

\section{Towards the endorsement of a mode of being in the world with the Other}

The previous section has explored the ontological understanding surrounding the concept of Saudization in contrast to the time-honored epistemological view. By examining the meaning of Saudization from an ontological hermeneutic perspective, the discussion moves forward towards a non-codification of the concept which provides stakeholders and researchers with a clarifying reading of work force localization while exploring the potential this reading holds for several stakeholders such as academicians, students, graduates, employers, and policy and decision makers; my aim is to stimulate new insights on Saudization as a concept and practice. The discussion has examined the ontological tradition that underscores the assumptions of nationalizing workforce. The educational ramifications of perceiving Saudization from ontological perspectives are considered as well in the following section.

\section{The ontology of Saudization}

The ontological perspective of Saudization entails an empowerment of the workforce with the required employability competences and skills that allow Saudi nationals to compete with the different professional Other (expatriates). Ontology, as such, opens a new hermeneutic horizon for another mindset that values the existing potential of foreign workforce. An ontological perspective towards workforce localization advances knowledge sharing, human resources development, talent management, and over and above skill development which are instrumental enablers for national Saudis to succeed in a knowledge and technology-based economy. An ontological world view towards the localization of workforce in Saudi Arabia turns private sector companies into learning organizations that value hermeneutic dialogue among entities of shared interests.

\section{Necessity of an ontological dialogue}

Developing and promoting a hermeneutic, ontological dialogue among stakeholders about the purpose of localizing the workforce in the KSA is a necessity. A hermeneutic dialogue, as a representation of the essence of our existence, needs to be recognized and fostered. As "beings in the world with others", all stakeholders of Saudization have to take part in the ontological conceptualization of the process that informs nationalizing Saudi workforce.

This discussion calls for an ontological turn towards the nationalization of workforce in the Kingdom of Saudi Arabia. Ontology, in this regard, promotes a reconceptualization of localizing the workforce, allowing stakeholders to focus more not on replacing the Other but rather on who they are becoming as employers or employees in relation and in contrast to the professional different and skilled Other. A shift in focus from epistemology to ontology provides insights on developing employable workforce empowered with required skills that allow them to compete with the Other. Ontologically, to be employable is to develop a way of thinking that sees oneself in reference and in contrast to the different Other. So, to localize the workforce is not to replace the Other, rather, it is the ability develop ways of perceiving oneself as part of the Other and act accordingly.

Heidegger (1995) rationalizes this process explaining that we are who we are because of beingin-the-world with others. The inevitability of being in the world with others makes it compelling, hermeneutically, according to Heidegger, for policy and decision makers to re-conceptualize the notion of nationalizing the Saudi workforce and consider the inevitability of the existing Other as an enriching human professional experience. The different professional Other is what gives identity to the national workforce (the Self). In fact, ontologically, both the Self and the Other need each other. So, the argument of the ontological turn that this discussion promotes calls for a shift in focus from replacing the Other (which after all you inevitably need her / him to see yourself differentially and referentially) to another focus on developing productive ways of empowering the national workforce (the self) with the required competences and skills that allow them to see how smart they are in relation to the inevitable different and skilled Other.

\section{Implication of an ontological perspective towards Saudization}

The shift in the conceptualization of nationalizing Saudi workforce from an epistemological mindset to another that is ontologically oriented should parallel a paradigm shift in higher education from 
epistemology to ontology; that is, higher education pedagogy needs to go beyond the time-honored epistemological trend that focuses on the amount of codified knowledge that students should acquire. A shift is needed from a focus on what learning/knowing is and how we learn/ should learn to an emphasis on what it means to learn and be employable, productive and beneficial not only to one's community but also to all other human beings across the globe. The ontology of education in higher institutions should consider the embedment of global competences and skills into the curriculum that allow Saudi nationals to compete in a competitive knowledge and technology-based economy and society. After all, a shift of focus is urgently needed to develop an ontologically-oriented hermeneutic understanding of what it means to be functional, employable, and productive in a knowledge and technology-driven society that needs both the Self and the Other.

\section{Conclusion}

This paper contributes to the growing discourse on man power localization in the context of Saudi Arabia. It addresses a gap in the literature concerning the absence of reading workforce localization from an ontologically-oriented hermeneutic standpoint. The ontological reading that this paper provides has the potential to engage stakeholders in a hermeneutic dialogue that explores in more depth the dimensions and consequences of perceiving Saudization epistemologically. A goal-oriented hermeneutic dialogue has the potential to open new horizons of understanding the value of the existing different and skilled Other. Within this scope of understanding, the different Other is perceived to be inevitably needed to develop a culture of leaning and knowledge sharing which are essential for the advancement of any knowledge-based economy such as that of the KSA.

The ontologically-oriented hermeneutic perspective towards manpower localization also is more likely to engage both the Self (the national manpower) and the Other (the foreign manpower) in codeveloping meaningful work-related experiences that enrich and enhance the knowledge and life style of the community as a whole. Considerably, an ontologically-oriented hermeneutic reading of Saudization would lead its stakeholders to:

- Develop strategic plans for empowering local manpower with the required competences and skills that allow them to compete with the different and skilled Other.

- Promote the development of organizational learning cultures that centralize generating strong and productive national and international workforces that have the potential to advance and improve the economy of the kingdom.

- Promote a pluralistic perception towards what it means to be employable and get a job, retain it and move to another if needed.

- Relate the concept of workforce localization to its contextualized practices.

- Advance a culture of appreciating the different intellectual and skilled Other.

After all, there is a clear need for a shift in focus from epistemology to an ontologically-oriented hermeneutic understanding of workforce localization in Saudi Arabia. There remains much more work to be done to conduct empirical research on workforce localization based on an ontologically-oriented conceptual framework. One way forward would be to conduct a mixed methods study that explores the extent and the way to which a hermeneutic reading of manpower localization can advance the development of meaningful interactions between the national and international workforces leading to the enhancement of the Kingdom of Saudi Arabia's economy.

\section{References}

Achoui M (2009). Human resource development in Gulf countries: An analysis of the trends and challenges facing Saudi Arabia. Human Resource Development International, 12(1): 35-46.

Al Asfour A and Khan S (2014). Workforce localization in the Kingdom of Saudi Arabia: issues and challenges. Human Resource Development International, 17(2): 243-253.

Al Asmari M (2008). Saudi labor force: Challenges and ambitions. JKAU: Arts \& Humanities, 16 (2): 19-59.

Al Dossary A (2004). HRD or manpower policy? Options for government intervention in the local labor market that depends upon a foreign labor force: the Saudi Arabian perspective. HRDI, 7(1): 123-135 
Al Dossary A and Rahman S. (2005). Saudization (Localization) - A Critical review. Human Resource Development International, 8 (4): 495 - 502.

Al Humaid M (2003). The factors affecting the process of Saudization in the private sector in the Kingdom of Saudi Arabia: A case study of Riyadh City. Ph.D. dissertation, The University of Exeter.

Al Khamis F (2001). Human resource development in Saudi Arabia: The college of technology role in supplying skilled manpower. Ph.D. dissertation, Mississippi State University.

Al-kibsi G, Woetzel J, Isherwood T, Khan J, Michke J, Noura H (2015). Saudi Arabia beyond oil: The investment and productivity transformation Mckinsey Global Institute. December. See also URL https://www.mckinsey.com/

Alogla H (1990). Obstacles to Saudization in the private sector of the Saudi Arabian labor force. Ph.D. dissertation, Michigan State University, USA.

Alotaibi A (2014). Opportunities and barriers to collaboration in addressing unemployment in Saudi Arabia. Ph.D. dissertation, University of La Verne, La Verne, California

Alshanbri $N$, Khalfan $M$ and Maqsood $T$ (2015). Localization barriers and the case of Nitaqat program in Saudi Arabiap. Journal of Economics, Business and Management, 3(9): 898-903.

Alshanbri N., Khalfan M., Noor M., Dutta D., Zhang K. and Maqsood T. (2015), Employees'turnover, knowledge management and human recourse management: A case of Nitaqat program. International Journal of Social Science and Humanity, 5 (8): 701-706.

Al Shammari S (2009). Saudization and skill formation for employment in the private sector. Ph.D. dissertation, University of Stirling.

Bruce H. (1995). An ontological approach to education. ERIC Document Reproduction Service No. 381830 .

CDSI (2014). Post-secondary enrollment. General Authority for Statistics. Kingdom of Saudi Arabia. See also URL https://www.stats.gov.sa/en

CDSI (2014). Post-secondary graduates. General Authority for Statistics. Kingdom of Saudi Arabia. See also URL https://www.stats.gov.sa/en

CDSI (2016). Workforce statistics. General Authority for Statistics. Kingdom of Saudi Arabia. See also URL https://www.stats.gov.sa/en

Ewain S (1999). Perceptions of employers and job seekers toward obstacles to Saudization of the workforce in the Saudi private sector. Ph.D. dissertation, Ohio State University.

Fakeeh M (2009). Saudization as a solution for unemployment: The case of Jeddah Western Region. Ph.D. dissertation, University of Glasgow.

Forstenlechner I (2009). Workforce localization in emerging Gulf economies: the need to fine-tune HRM, Personnel Review, 39 (1): $135-152$.

Gadamer $H$ (1977). Philosophical hermeneutics. Trans. David Linge. Berkeley, University of California. Available online from:

h t t p : //www. west minster. edu/staff/nak/courses/documents/ Gadamer\%20Philosophical\%20Hermeneutics.pdf

Harry $W$ (2007). Employment creation and localization: The crucial human resource issues for the GCC”. Int. J. of Human Resource Management 18 (1):132-146. 
The Turkish Online Journal of Design, Art and Communication - TOJDAC

ISSN: 2146-5193, September 2018 Special Edition, p.1195-1206

Heidegger M. (1995). Being and time. New York, NY: Harper \& Row. Available online from: http:// www. naturalthinker.net/trl/texts/Heidegger, Martin/Heidegger, \%20Martin\%20\%20Being\%20and\%20Time/Being\%20and\%20Time.pdf

Madhi S and Barrientos A (2003). Saudisation and employment in Saudi Arabia. Career Development International, 8 (2): 70 - 77.

Maghrabi A (1997). Modeling the vonnection between population growth and unemployment rate. Ph.D. dissertation, Mississippi State University.

Nolan L (2011). Keeping the Kingdom: The Politics of Higher Education Reform in Saudi Arabia. Ph.D. dissertation, Tufts University Medford, MA.

Rescher N (2003). Epistemology: An Introduction to the Theory of Knowledge. State University of New York. Available from: http://riclc.ut.ac.ir/images/booklibrary/9.pdf

Sadi $M$ (2013). The Implementation process of nationalization of workforce in Saudi Arabian private sector: A review of Nitaqat scheme. American Journal of Business and Management 2 (1): $37-45$.

Sadi $M$ and Henderson J (2010). Towards job localization in Saudi Arabia: Drivers and barriers within the services industry. Journal of Immigrant \& Refugee Studies, 8 (2): 121-134.

Sadi $M$ and Al Buraey A (2009). A Framework of the implementation process: The Case of Saudization. International Management Review 5 (1): 70-106.

SAGIA (2016). Facts and statistics: Saudi Arabia. Saudi Arabian General Investment Authority. See also URL https://www.sagia.gov.sa/

Swailes S., Al Said G. and Al Fahdi S (2012) Localisation policy in Oman: a psychological contracting interpretation. International Journal of Public Sector Management 25

(5): $357-372$.

Sartre J (1956). Being and nothingness. New York: Philosophical Library. 